\title{
Kvalita vody pražských potoků. Část 1: Motolský a Litovický potok
}

\section{BLANKA DESORTOVÁ, LADISLAV HAVEL, JAN ŠŤASTNÝ}

Klíčová slova: pražské potoky - kvalita vody - živiny - fytoplankton - zooplankton

\section{SOUHRN}

Článek shrnuje výsledky sledování kvality vody ve vybraných profilech Motolského a Litovického potoka, které probíhalo v roce 2018. Sledování bylo zaměřeno na změny obsahu živin (formy dusíku a fosforu), koncentrace chlorofylu-a a na kvalitativní složení společenstva fytoplanktonu a zooplanktonu. Získané výsledky ukázaly horší stav $v$ Litovickém potoce ve srovnání s Motolským potokem jak z hlediska obsahu živin, tak biomasy fytoplanktonu. Kvalita vody v Litovickém potoce je ovlivňována zejména prísunem znečištění ze zemědělsky využívané krajiny, prísunem komunálního znečištění a vodou odtékající z čistíren odpadních vod v povodí potoka.

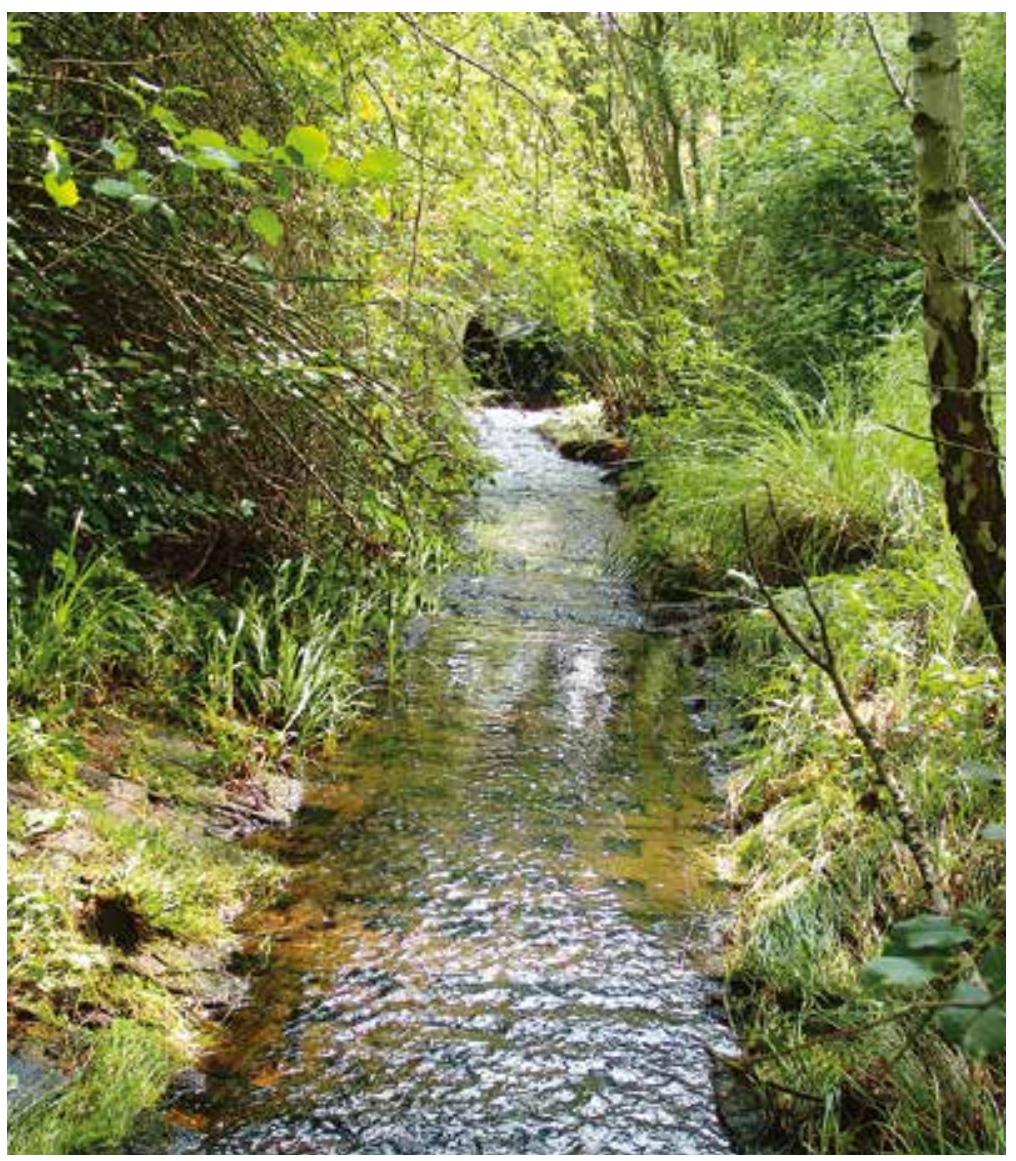

Obr. 1. Motolský potok, profil Zličín

Fig. 1. Motolský stream, the profile Zličín

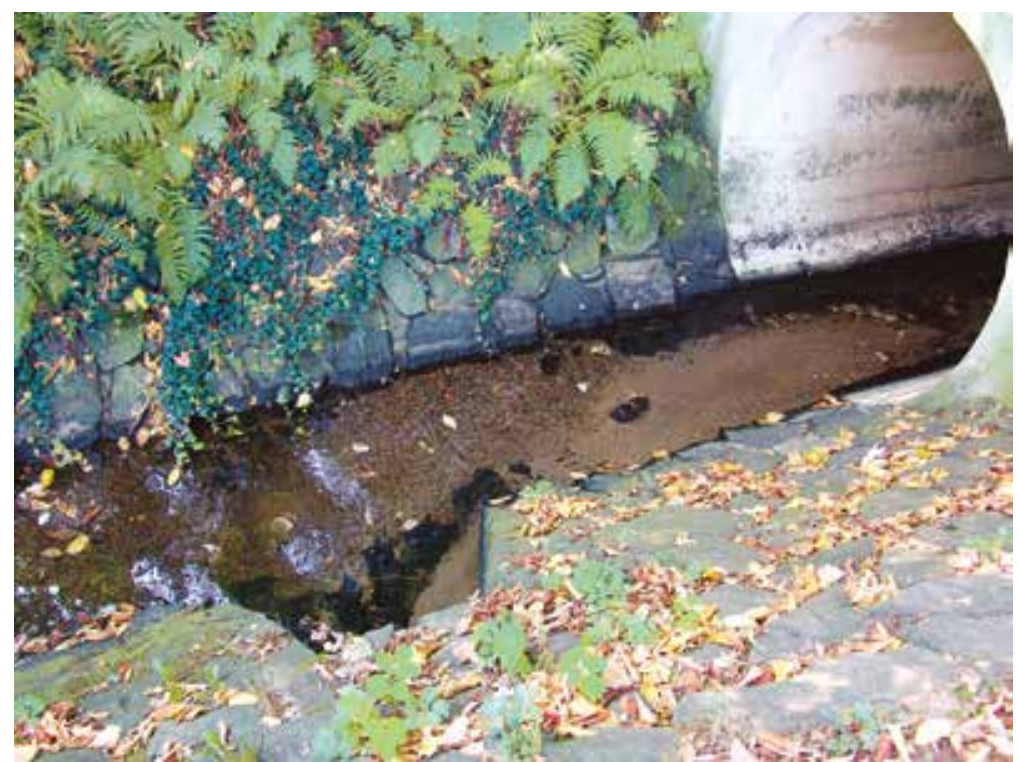

Obr. 2. Motolský potok, prítok do Mlýnského rybníka Fig. 2. Motolský stream, inflow to the Mlýnský pond

\section{ÚVOD}

V průběhu roku 2018 bylo prováděno sledování kvality vody ve vybraných profilech Motolského a Litovického potoka, které jsou významnými (páteřními) vodními toky západní části pražské aglomerace a na jejichž toku jsou využívaná prírodní koupaliště. Zatímco povodí Motolského potoka leží pouze na území hlavního města Prahy, povodí Litovického potoka zasahuje svou horní částí do území Středočeského kraje. Na obou sledovaných potocích se nachází řada rybníků a nádrží, z nichž některé jsou určitým způsobem využívány (rybářství, rekreace), případně mají retenční úlohu.

Motolský potok (délka toku 9,9km) pramení v oblasti Zličína, v blízkosti konečné stanice metra. Po krátkém, přibližně kilometrovém, toku otevřeným korytem (obr. 1) vtéká do podzemí, ze kterého se dostává na povrch u Motolského krematoria (obr. 2), kde napájí Mlýnský rybník. V jeho zatrubněné části do něj ústí zprava Větvený potok s retenční nádrží Brouček. Po odtoku z Mlýnského rybníka (obr. 3) pokračuje potok krátkým úsekem volné vody a znovu vtéká do podzemí, kde se dělí na dvě části. Pravá část prochází rybníkem Pivovarský, pokračuje krátkým otevřeným úsekem (obr. 4) a následně se potrubím pod Plzeňskou ulicí dostává na levou stranu, kde se později spojuje s druhou, levou částí. Levá část Motolského potoka podchází Plzeňskou 

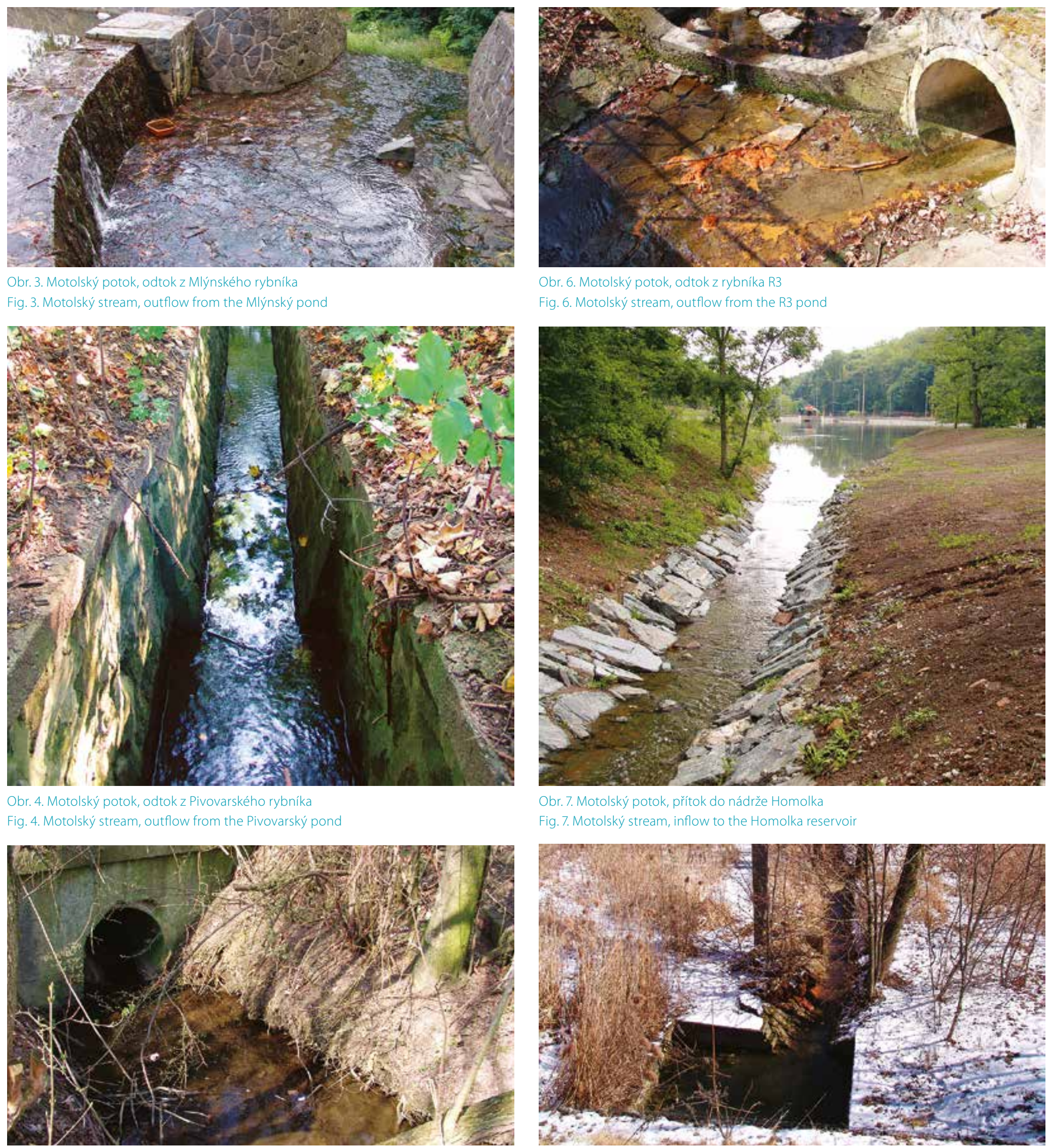

\section{Obr. 5. Motolsky potok, pritok do rybnika RT}

Obr. 8. Litovický potok, odtok z rybníka Baśta 

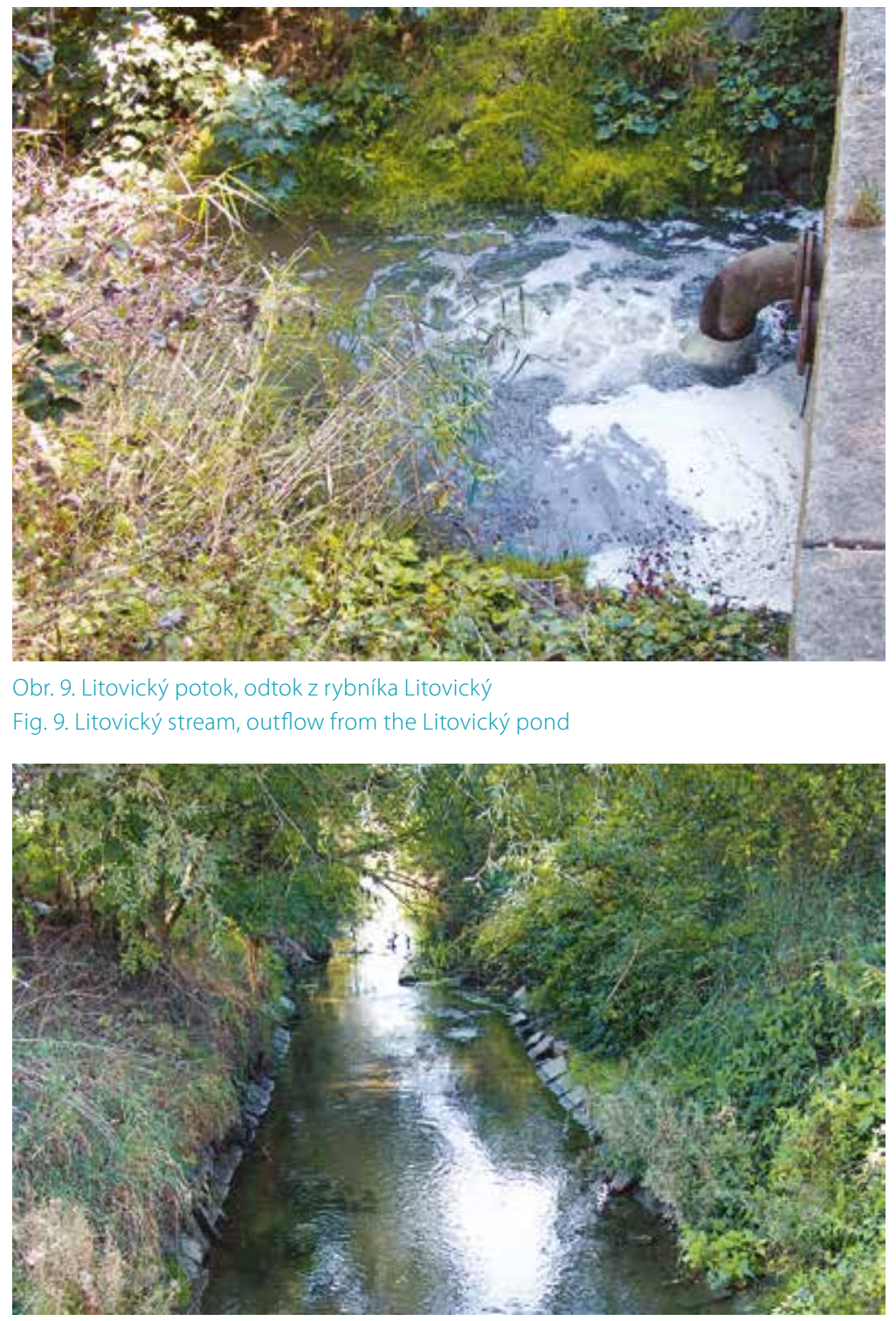

Obr. 10. Litovický potok, přítok do nádrže Strnad

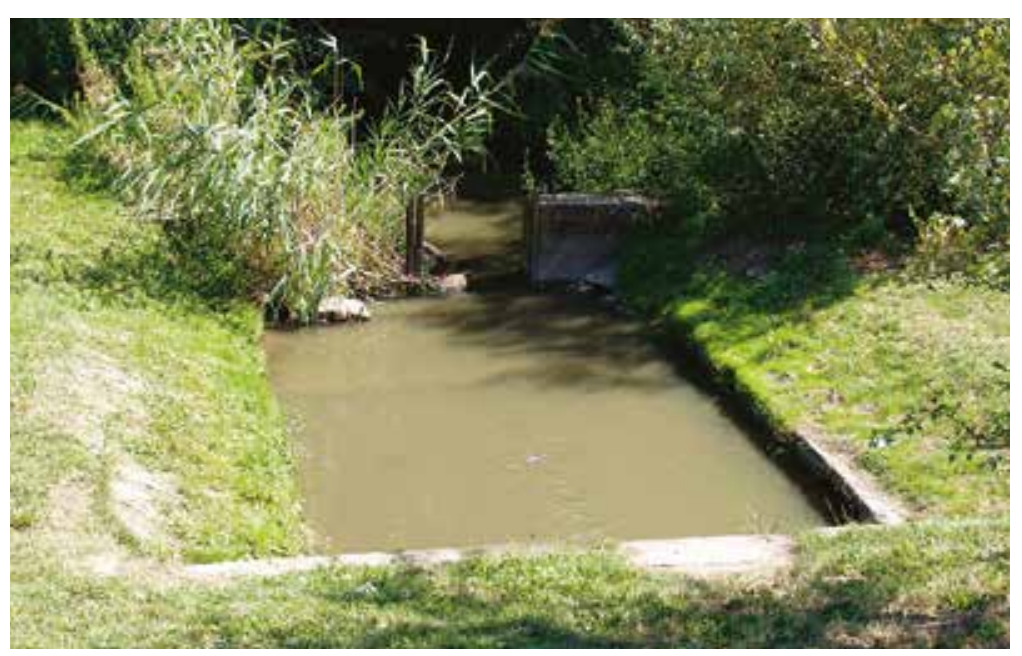

Obr. 11. Litovický potok, odtok z nádrže Strnad

Fig. 11. Litovický stream, outflow from the Strnad reservoir

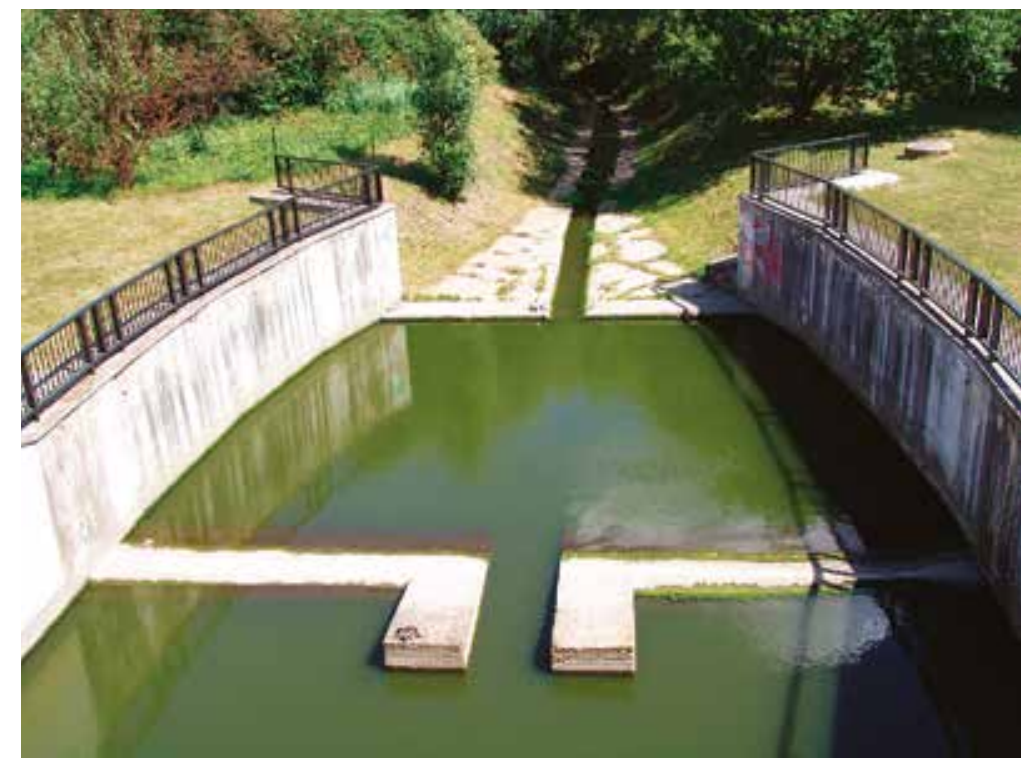

Fig. 12. Litovický stream, outflow from the Jiviny reservoir

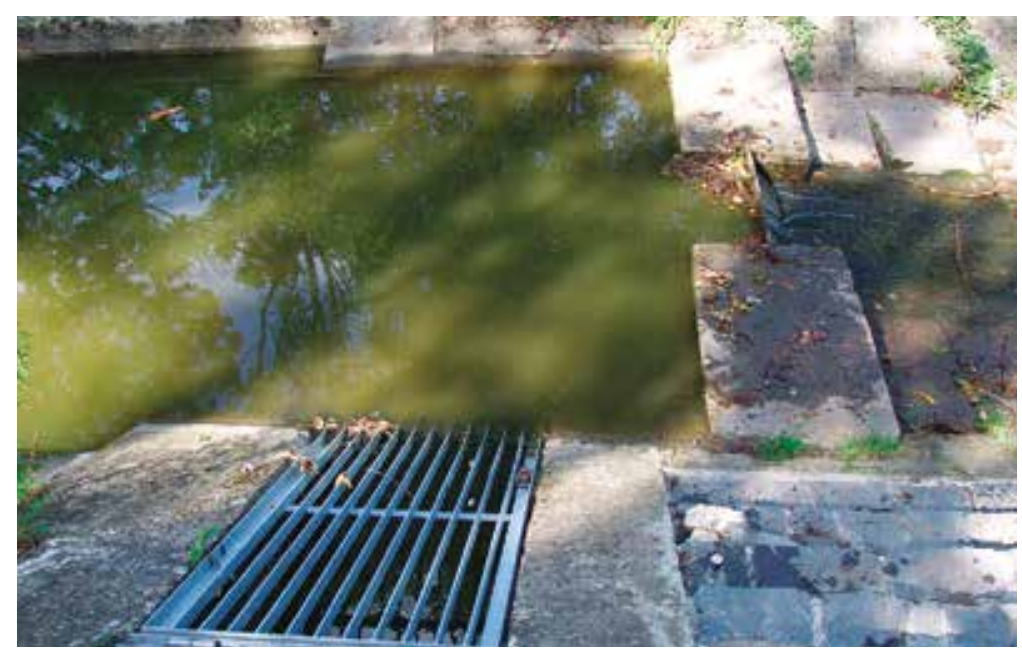

Obr. 13. Litovický potok, prrítok do rybníka Libocký
Fig. 13. Litovický stream, inflow to the Libocký pond

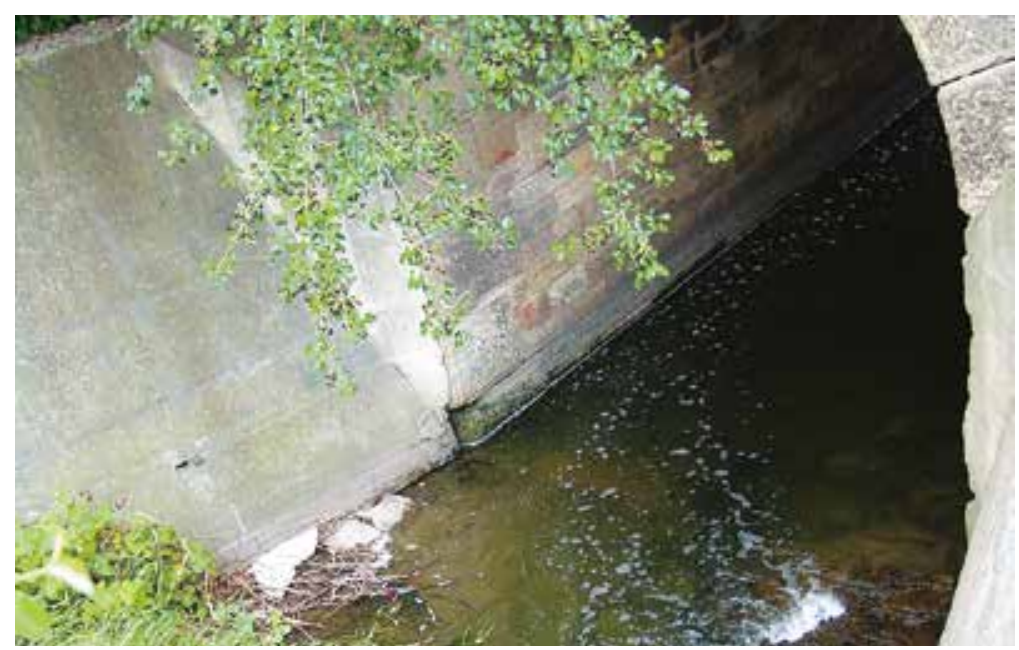

Obr. 14. Litovický potok, odtok z rybníka Libocký

Fig. 14. Litovický stream, outflow from the Libocký pond 
Tabulka 1. Seznam odběrových míst

Table 1. List of sampling sites

\begin{tabular}{ll}
$\begin{array}{l}\text { Motolský potok } \\
\text { Profil }\end{array}$ & Číslo lokality na mapě \\
\hline Zličín & 1 \\
\hline Mlýnský rybník - přitok & 2 \\
\hline Mlýnský rybník - odtok & 3 \\
\hline Pivovarský rybník - odtok & 4 \\
\hline Rybník R1 - přítok & 5 \\
\hline Rybník R1 - odtok & 6 \\
\hline Rybník R2 - odtok & 7 \\
\hline Rybník R3 - odtok & 8 \\
\hline Nádrž Homolka - přítok & 9 \\
\hline Nádrž Homolka - odtok & 10 \\
\hline
\end{tabular}

\section{Litovický potok \\ Profil}

\begin{tabular}{ll}
\hline Rybník Bašta - odtok & 1 \\
\hline Strahovský rybník - odtok & 2 \\
\hline Litovický rybník - odtok & 3 \\
\hline Nádrž Strnad - př́tok & 4 \\
\hline Nádrž Strnad - odtok & 5 \\
\hline Nádrž Jiviny - odtok & 6 \\
\hline Libocký rybník - prítok & 7 \\
\hline
\end{tabular}

Libocký rybník - odtok

8

Nádrž Džbán - př́tok

Nádrž Džbán - odtok

10

ulici hned po rozdělení toku, částečně volně a částečně podzemím přitéká do soustavy tří propojených motolských rybníků (R1, R2, R3), které napájí (obr. 5). Prostřední rybník R2 je v letním období využíván k rekreaci a koupání jako přírodní koupaliště. Po odtoku z rybníka R3 (obr. 6) pokračuje potok volně korytem, zprava přibírá potok Cibulka, podzemím podchází Plzeňskou ulici a na hranici lesoparku Cibulka vtéká do nově vybudované nádrže Homolka (obr. 7). Z nádrže Homolka odtéká Motolský potok podzemím pod oblastí Košiř a Smíchova a přibližně po čtyřech kilometrech ústí zleva do Vltavy mezi Palackého a Jiráskovým mostem [1].

Litovický potok (délka toku 13,3 km), resp. Litovicko-Šárecký potok (celková délka 24,3km), pramení v oblasti obce Chýně ve Středočeském kraji, v blízkosti západního okraje Prahy. Potok postupně protéká soustavou navazujících rybníků Bašta (obr. 8), Strahovský a Břve, odkud se voda dostává do Litovického rybníka. Rybník Strahovský je intenzivně rybářsky využíván, rybník Břve je využíván k rekreaci. Odtoková voda z Litovického rybníka (obr. 9) pokračuje volným

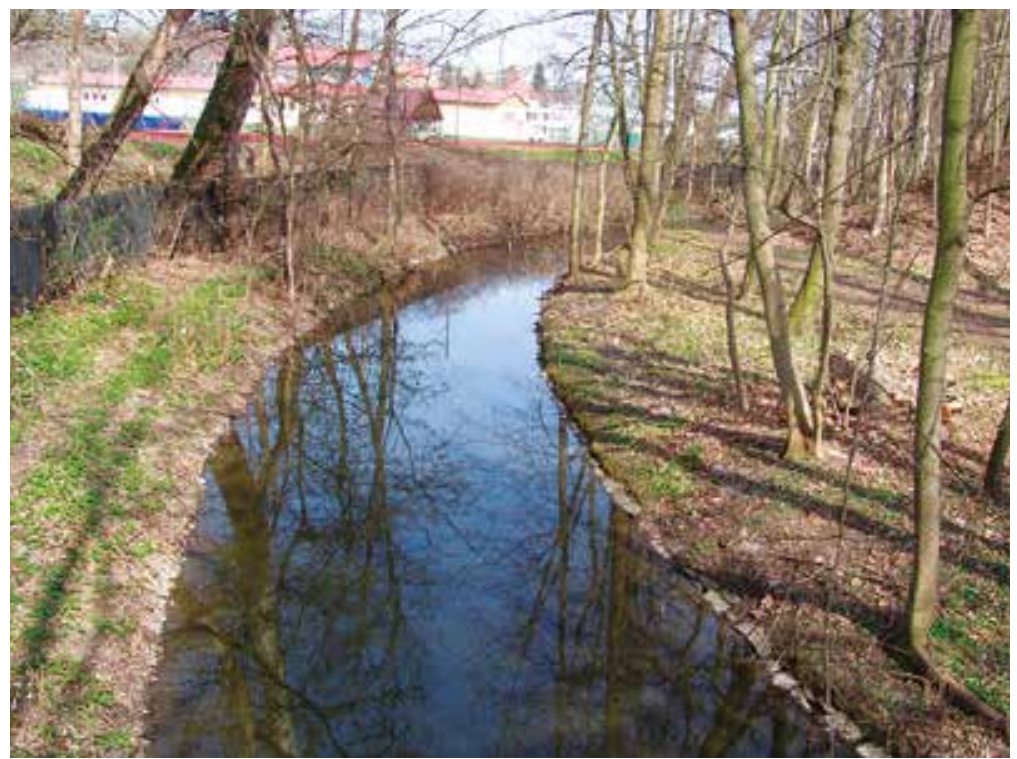

Obr. 15. Litovický potok, prítok do nádrže Džbán

Fig. 15. Litovický stream, inflow to the Džbán reservoir

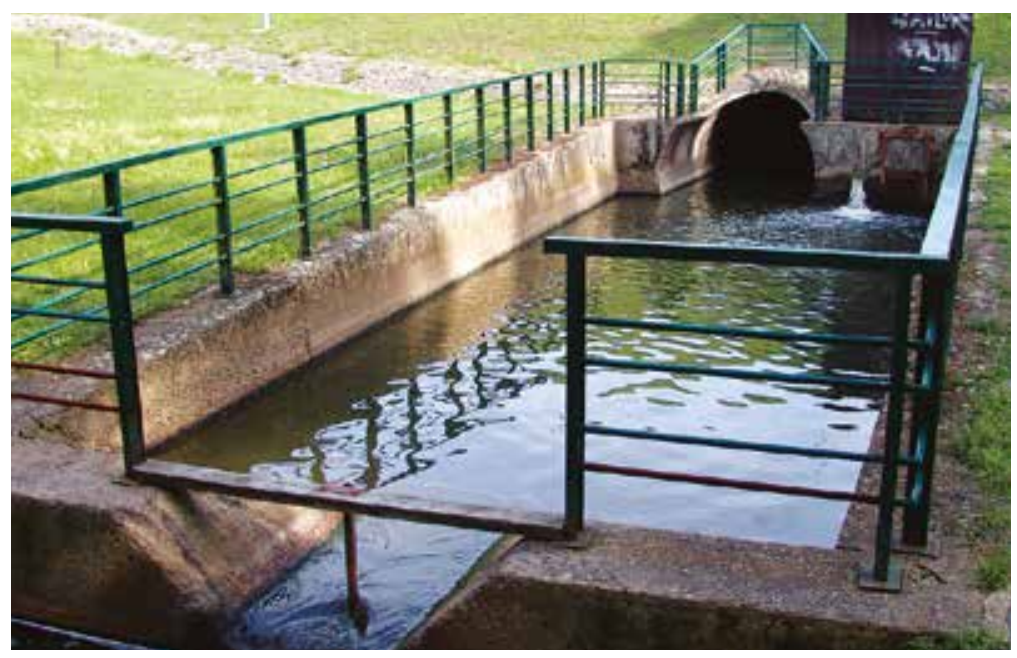

Obr. 16. Litovický potok, odtok z nádrže Džbán

Fig. 16. Litovický stream, outflow from the Džbán reservoir

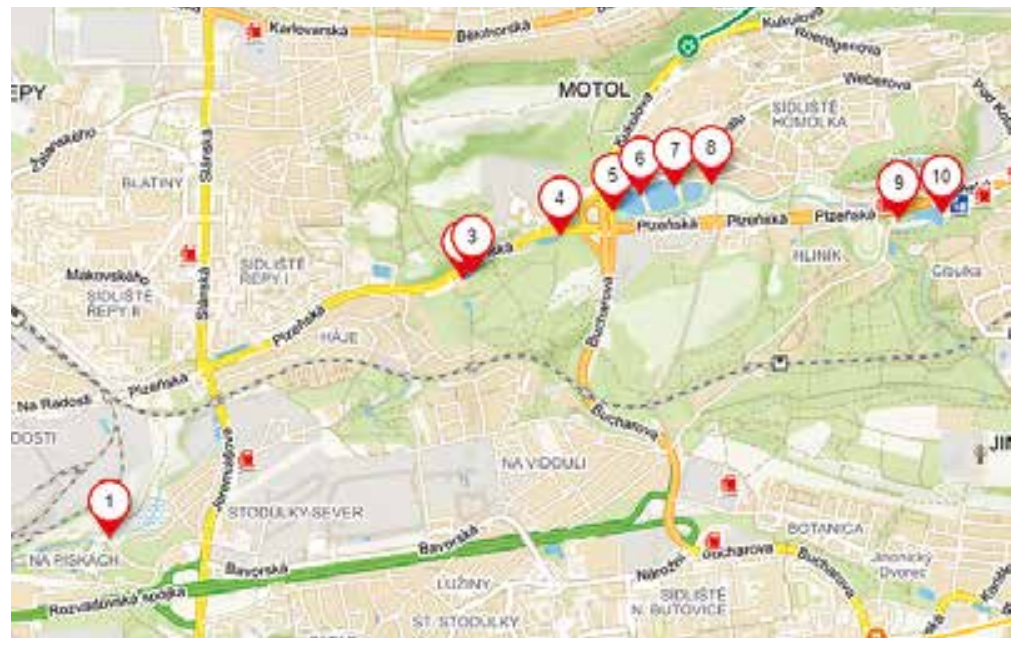

Obr. 17. Odběrová místa na Motolském potoce

Fig. 17. Sampling sites on the Motolský stream 


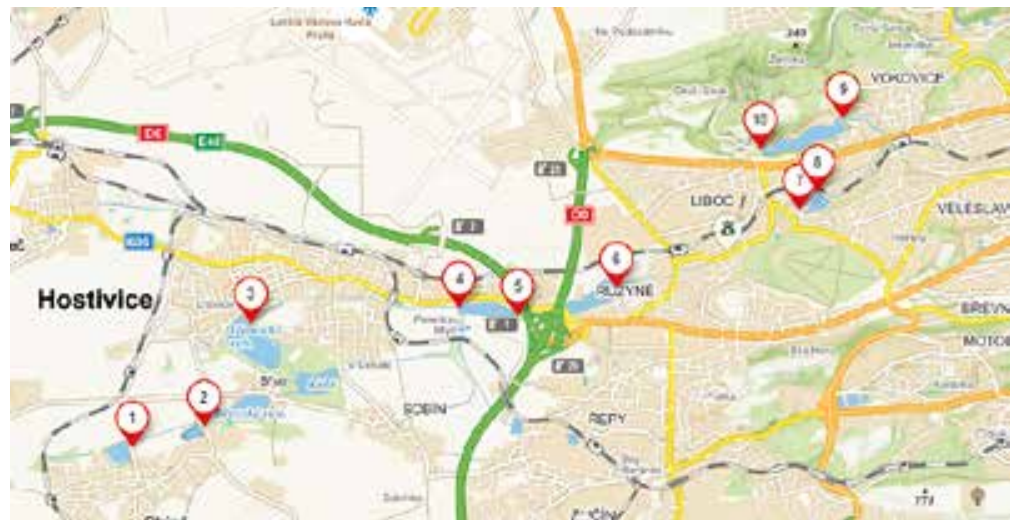

Obr. 18. Odběrová místa na Litovickém potoce

Fig. 18. Sampling sites on the Litovický stream

úsekem přes město Hostivice, kde se zleva připojuje Jenečský potok, dále do nádrže Strnad (obr. 10) se zaústěním Zličínského potoka. Po průchodu nádrží Strnad (obr. 11) pokračuje potok do retenční nádrže Jiviny na území Prahy-Ruzyně. Do nádrže přitéká zprava potok Řepský. Po výtoku z nádrže Jiviny (obr. 12) pokračuje potok krátce volným úsekem, následně podzemím prochází pod částí Ruzyně, vynořuje se pod oborou Hvězda a volně přitéká k Libockému rybníku. Část vody z Litovického potoka rybník napájí (obr. 13) a část teče dále obtokovým korytem. Odtok z Libockého rybníka pak ústí zpět do obtoku (obr. 14). Litovický potok následně pokračuje oblastí Liboce a Veleslavína a do nádrže Džbán (obr. 15), z nádrže vytéká v oblasti Divoké Šárky (obr. 16). Poté co protekl Šáreckým údolím jako Litovicko-Šárecký potok ústí zleva do Vltavy v Praze-Podbabě [2].
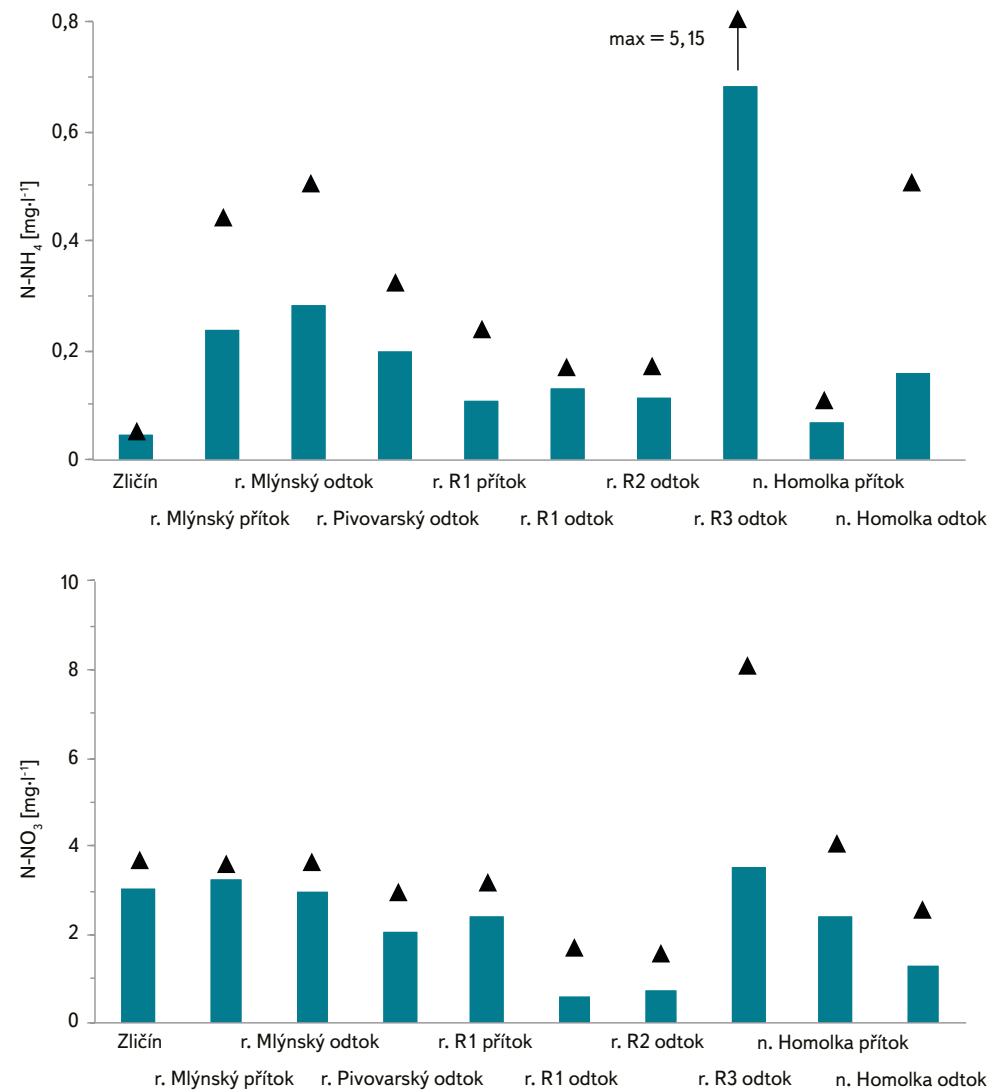

\section{LOKALITY A METODIKA}

Vzorky pro sledování kvality vody Motolského a Litovického potoka byly odebírány 1× měsíčně v období březen až listopad roku 2018. Seznam odběrových míst je uveden $v$ tabulce 1, jejich poloha je znázorněna na mapách na obr. 17 (Motolský potok) a obr. 18 (Litovický potok). Podkladové mapy byly převzaty z portálu Mapy.cz.

Vzorky vody byly odebírány prevážně na př́toku a odtoku z rybníků a nádrží. Odběry v terénu doprovázelo in-situ měření fyzikálně-chemických charakteristik kvality vody (teplota, pH, koncentrace rozpuštěného kyslíku, nasycení vody kyslíkem). Laboratorní analýzy vzorků byly zaměřeny na stanovení jednotlivých forem dusíku (N-NH$H_{4^{\prime}} \mathrm{N}-\mathrm{NO}_{3^{\prime}} \mathrm{N}-\mathrm{NO}_{2^{\prime}} \mathrm{N}$-organický, N-celkový) a fosforu ( $\mathrm{P}_{-} \mathrm{PO}_{4^{\prime}}$ P-celkový). Hydrobiologické analýzy vzorků zahrnovaly stanovení koncentrace chlorofylu-a jako měřítka biomasy fytoplanktonu a kvalitativní složení společenstva fytoplanktonu a zooplanktonu. Odběry vzorků a následné analýzy byly prováděny standardními postupy podle ČSN ISO [3-8], popř. metodami běžnými v limnologickém výzkumu.

\section{VÝSLEDKY A DISKUSE}

\section{Motolský potok}

Na obr. 19 jsou znázorněny průměrné a maximální hodnoty koncentrací $\mathrm{N}-\mathrm{NH}_{4^{\prime}}$ $\mathrm{N}-\mathrm{NO}_{3^{\prime}}, \mathrm{P}_{-} \mathrm{PO}_{4}$ a P-celk. ve sledovaných profilech Motolského potoka $\vee$ daném období. Horní úsek toku (profil Zličín) charakterizují nízké průměrné i maximální
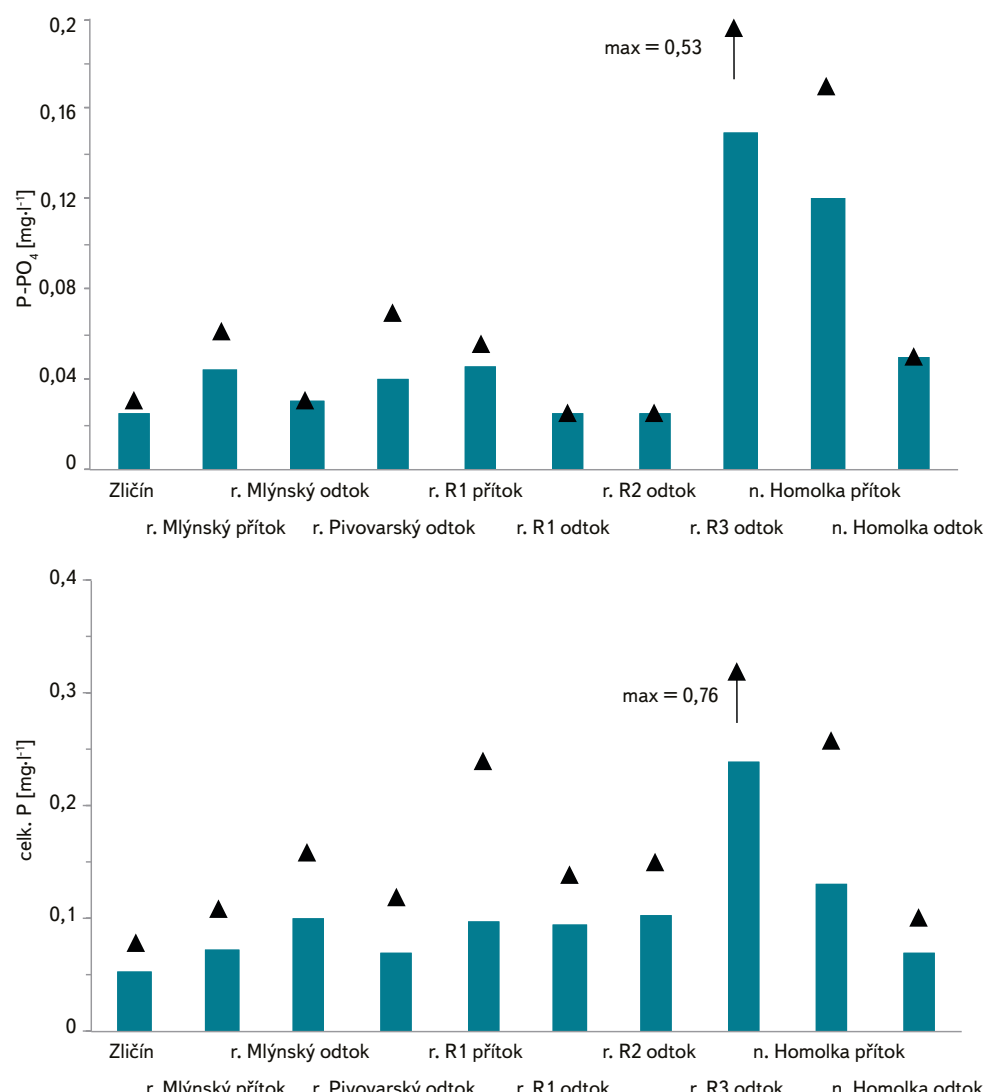

Obr. 19. Prưměrné a maximální hodnoty $\mathrm{N}-\mathrm{NH}_{4^{\prime}} \mathrm{N}-\mathrm{NO}_{3^{\prime}}, \mathrm{P}_{-} \mathrm{PO}_{4}$ a P-celk. ve sledovaných profilech na Motolském potoce (sloupec $=$ průměr, trojúhelníček = maximum) Fig. 19. Mean and maximum values of $\mathrm{N}-\mathrm{NH}_{4}, \mathrm{~N}-\mathrm{NO}_{3}, \mathrm{P}_{-} \mathrm{PO}_{4}$ and $\mathrm{P}$-celk. in the studied profiles on the Motolský stream (column $=$ mean, triangle $=$ maximum) 

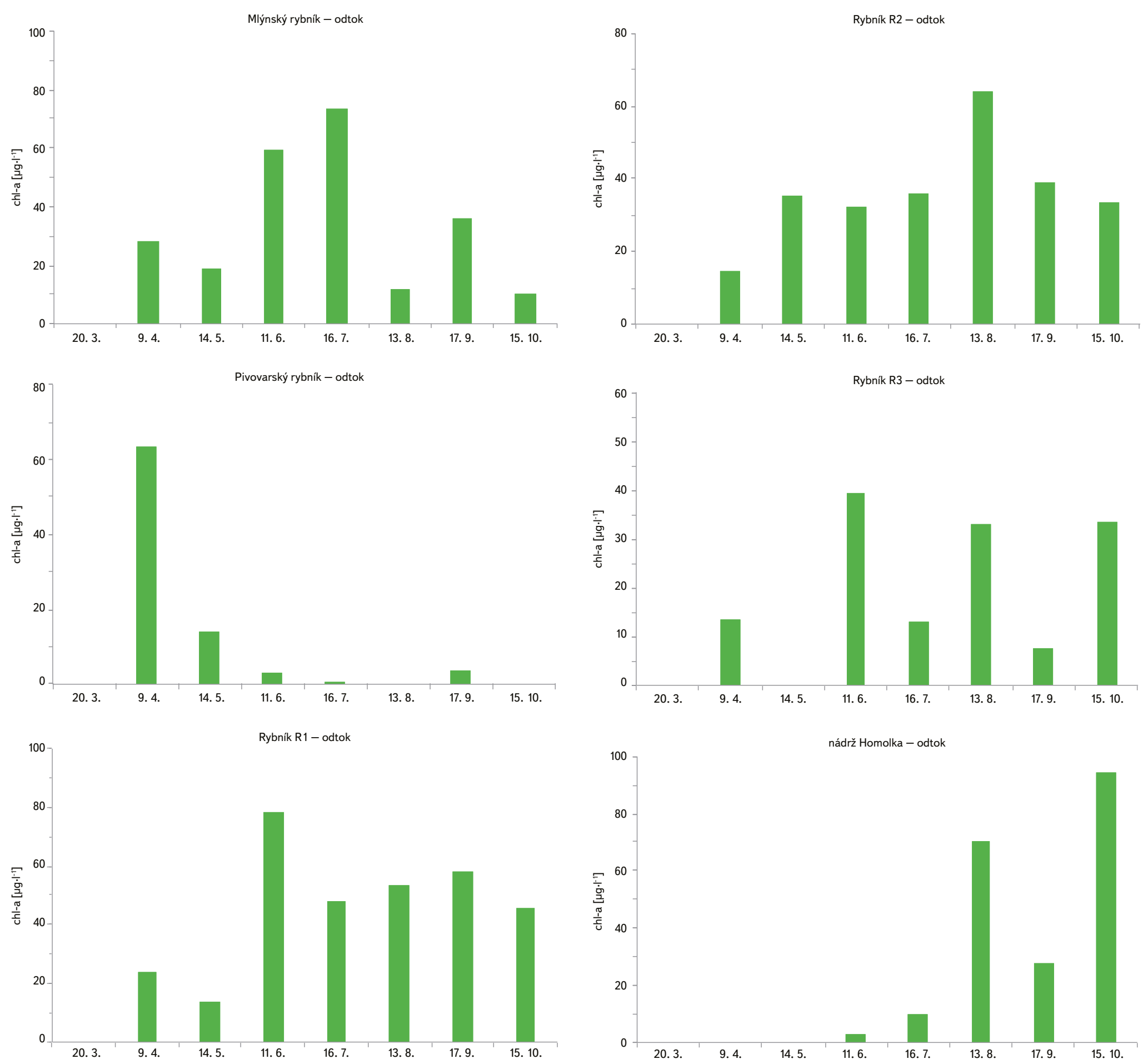

Obr. 20. Sezonní změny koncentrace chlorofylu-a ve sledovaných profilech Motolského potoka

Fig. 20. Seasonal changes of chlorophyll-a concentration in the studied profiles on the Motolský stream

hodnoty vybraných ukazatelů kvality vody. Výjimkou jsou hodnoty $\mathrm{N}-\mathrm{NO}_{3^{\prime}}$ které jsou identické $s$ údaji $v$ následujících profilech. Hodnoty koncentrací forem dusíku a fosforu jsou v lokalitách pod výstupem toku z podzemí - po odtok z rybníka R2 - vyšší ve srovnání s horním úsekem. V těchto lokalitách se průměrné hodnoty $\mathrm{N}-\mathrm{NH}_{4}$ pohybovaly $\vee$ rozmezí 0,11-0,28 mg. $\mathrm{I}^{-1}, \mathrm{~N}-\mathrm{NO}_{3} \quad 0,57-3,24 \mathrm{mg} . \mathrm{I}^{-1}$, P-PO $4,03-0,05$ mg..$^{-1}$ a P-celk. 0,07-0,10 mg..$^{-1}$. Výrazné zvýšení jak průměrných, tak zejména maximálních hodnot koncentrace forem dusíku a fosforu bylo zjištěno na odtoku z rybníka R3. V tomto profilu dosáhla např. maximální koncentrace $\mathrm{N}_{-} \mathrm{NH}_{4}$ hodnoty $5,15 \mathrm{mg} . \mathrm{I}^{-1}$ a P-celk. 0,76 mg. . $^{-1}$. Zjevný pokles hodnot sledovaných ukazatelů kvality vody byl zaznamenán před zaústěním Motolského potoka do podzemního závěrečného úseku (obr. 19).

Změny obsahu chlorofylu-a (měŕítko biomasy fytoplanktonu) během vegetační sezony (tj. březen-ř́ijen) jsou pro vybrané profily Motolského potoka graficky znázorněny na obr. 20. V některých termínech hodnoty v grafech chybí. 

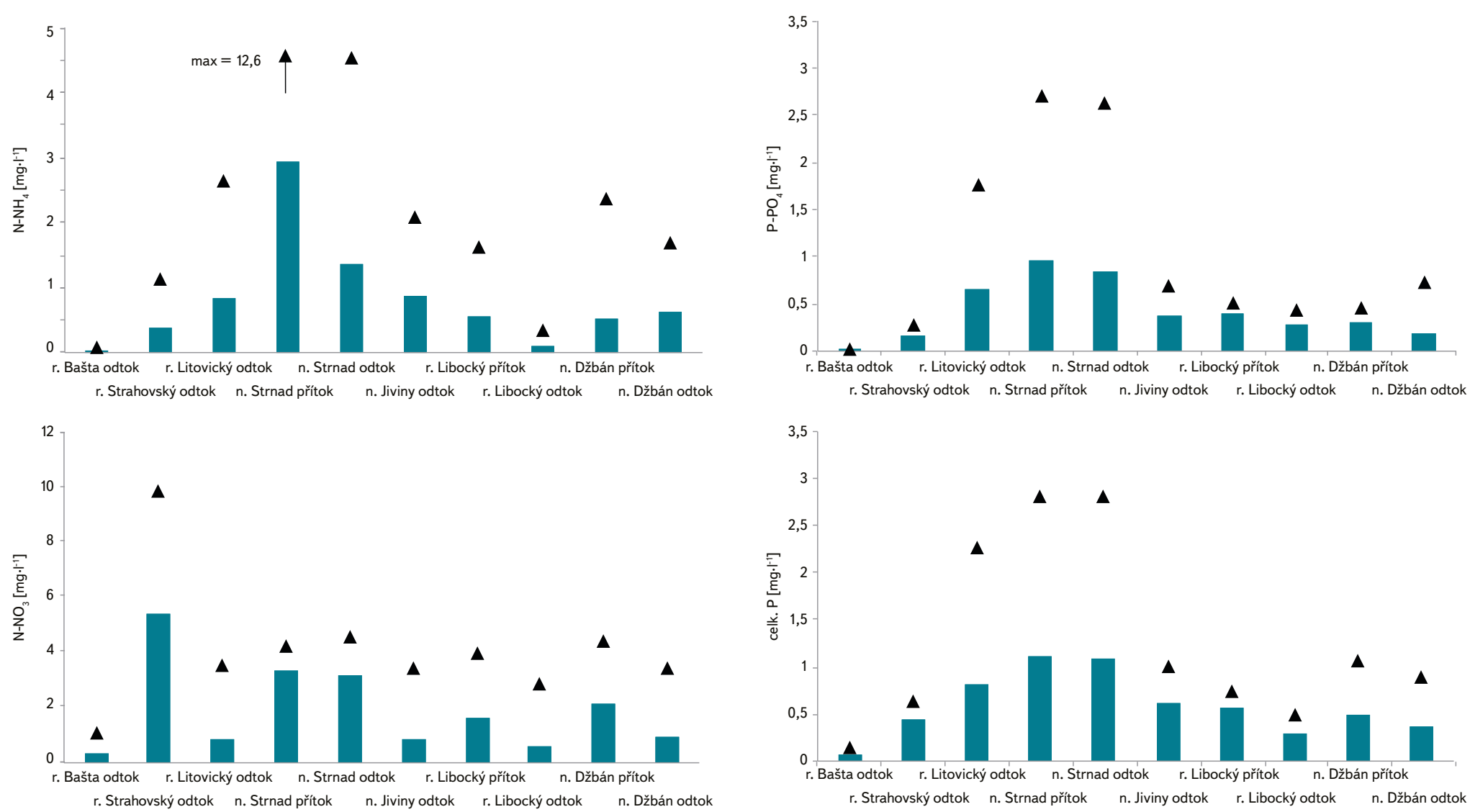

Obr. 21. Průměrné a maximální hodnoty $\mathrm{N}-\mathrm{NH}_{4}, \mathrm{~N}-\mathrm{NO}_{3}, \mathrm{P}_{-} \mathrm{PO}_{4}$ a P-celk. ve sledovaných profilech Litovického potoka (sloupec $=$ průměr, trojúhelníček = maximum)

Fig. 21. Mean and maximum values of $\mathrm{N}-\mathrm{NH}_{4}, \mathrm{~N}-\mathrm{NO}_{3}, \mathrm{P}_{-} \mathrm{PO}_{4}$ and $\mathrm{P}$-celk. in the studied profiles on the Litovický stream (column $=$ mean, triangle $=$ maximum)

Vzhledem k extrémnímu suchu, nedostatku srážek v průběhu roku 2018 a k nutnosti zajistit podmínky pro rybí obsádku voda z rybníků neodtékala. Hodnoty chlorofylu-a zjištěné na odtocích z rybníků (Mlýnský, R1 a R2) zejména v letním období dokumentují výskyt vysoké biomasy fytoplanktonu ve vlastních rybnících. Rozvoj biomasy fytoplanktonu vedl v rybnících ke vzniku vegetačního zákalu a poklesu průhlednosti vody. Hodnoty průhlednosti vody měřené v rybnících se pohybovaly v rozmezí 0,5-0,8 m. Charakter změn obsahu chlorofylu-a na odtoku z rybníka Pivovarský a z nádrže Homolka se od ostatních profilů liší. Vysoká počáteční koncentrace chlorofylu-a $\left(63,8\right.$ g..$\left.^{-1}\right)$ na odtoku z Pivovarského rybníka poklesla na nízkou úroveň, která se udržela do konce vegetační sezony. Důvodem bylo postupné až úplné zarůstání rybníka makrovegetací, zhoršení světelných podmínek ve vodním sloupci omezující rozvoj fytoplanktonu. Nádrž Homolka se v průběhu jarního období teprve plnila vodou. V závěru vegetační sezony byla na odtoku z nádrže zjištěna nejvyšší hodnota biomasy fytoplanktonu (chlorofyl-a 94,1 $\mu \mathrm{g} . \mathrm{I}^{-1}$ ) ze všech sledovaných lokalit.

\section{Litovický potok}

Úroveň živin ve sledovaných profilech Litovického potoka dokumentuje obr. 21, na kterém jsou znázorněny průměrné a maximální hodnoty koncentrací $\mathrm{N}-\mathrm{NH}_{4^{\prime}}$ $\mathrm{N}-\mathrm{NO}_{3^{\prime}}, \mathrm{P} \mathrm{PO}_{4}$ a P-celk. $v$ daném období. Z porovnání rozsahu hodnot v jednotlivých grafech na obr. 19 a 21 je zřejmé, že obsah sledovaných živin je v Litovickém potoce významně vyšší než v Motolském potoce. Především se to týká koncentrací $\mathrm{N}-\mathrm{NH}_{4^{\prime}} \mathrm{P}_{-} \mathrm{PO}_{4}$ a P-celk. Koncentrace živin $\vee$ profilech Litovického potoka se postupně zvyšuje od horního úseku toku, odtok z rybníku Bašta, po prítok do nádrže Strnad (v roce 2018 vypuštěná, odstraňování sedimentu - napouštění začalo až v ríjnu, přičemž veškerá vzrostlá makrovegetace byla ponechána na místě a opět zaplavena). Kvalita vody je $v$ tomto profilu ovlivněna prísunem vody odtékající z čistírny odpadních vod umístěné pod městem Hostivice. Na př́toku do nádrže Strnad byla zjištěna maximální koncentrace P-celk. 2,8 mg.l-1 a maximální hodnota $\mathrm{N}-\mathrm{NH}_{4}$ 12,6 $\mathrm{mg}^{-1} \mathrm{I}^{-1}$. V profilech umístěných na úseku toku pod nádrží Strnad se jak průměrné, tak maximální hodnoty forem fosforu a dusíku (s výjimkou N-NH ) udržovaly na nižší úrovni. Průměrné hodnoty $\mathrm{N}-\mathrm{NH}_{4}$ se pohybovaly $\vee$ rozmezí 0,12-1,37 mg. $\mathrm{I}^{-1}, \mathrm{~N}-\mathrm{NO}_{3} 0,61-2,18 \mathrm{mg}^{-1} \mathrm{I}^{-1}$,

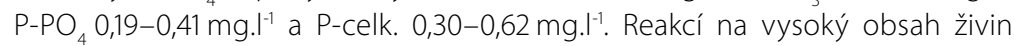
$\checkmark$ ekosystémech povrchových vod, zejména stojatých a pomalu tekoucích, je rozvoj autotrofních organismů. Objevuje se vysoká biomasa mikroskopických sinic a řas nebo dochází ke zvýšenému rozvoji vodních makrofyt.

Změny obsahu chlorofylu-a během vegetační sezony jsou pro vybrané profily Litovického potoka znázorněny na obr. 22. Ve všech profilech, s výjimkou odtoku z rybníků Litovický a Libocký, byly zjištěny vysoké koncentrace chlorofylu-a, které dosahovaly hodnot 250-360 $\mu \mathrm{g} \mathrm{I}^{-1}$. Průhlednost vody měřená v rybnících nad odtokovými profily byla za těchto podmínek na úrovni 0,30-0,40 m. Nízké hodnoty biomasy fytoplanktonu na odtoku z Litovického rybníka jsou ovlivněny tím, že z rybníka odtéká voda ze spodních vrstev (viz obr. 9), zatímco fytoplankton se vyskytuje predevším v horní prosvětlené (eufotické) vrstvě vody. Do spodních vrstev se pak fytoplankton dostává sedimentací vesměs odumírajících jedinců. V odtoku z Libockého rybníka byla časně na jaře zjištěna hodnota koncentrace chlorofylu-a $35 \mu \mathrm{g} \mathrm{I}^{-1}$, do konce vegetační sezony byl obsah chlorofylu-a velmi nízký (chlorofyl-a 0,6-4,0 $\mu$ g. I $^{-1}$ ). Na jaře a počátkem léta bylo množství fytoplanktonu v Libockém rybníce udržováno na nízké úrovni predačním tlakem př́tomného zooplanktonu (viz kapitola zooplankton). 

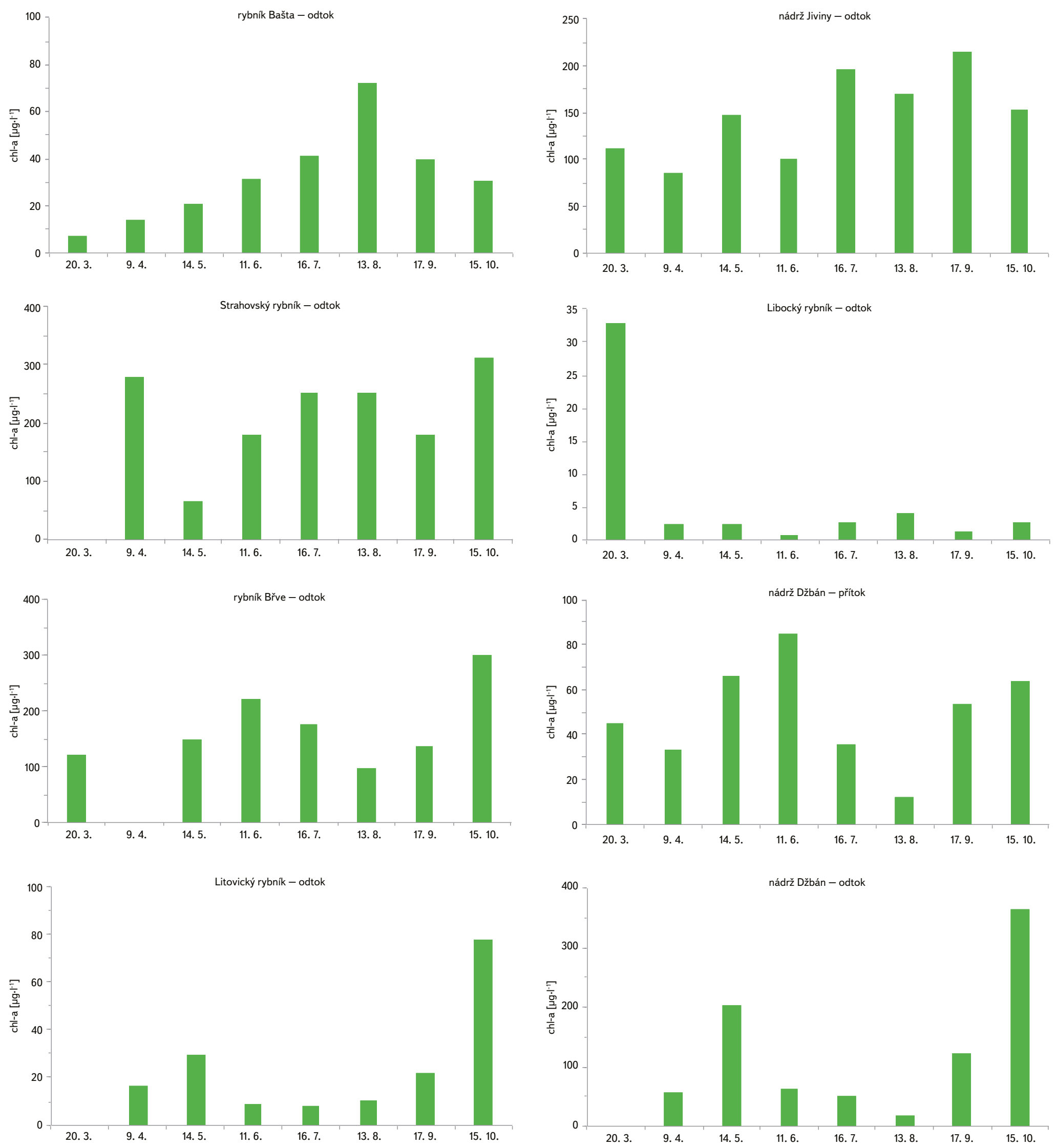

Obr. 22. Sezonní změny koncentrace chlorofylu-a ve sledovaných profilech Litovického potoka

Fig. 22. Seasonal changes of chlorophyll-a concentration in the studied profiles on the Litovický stream 


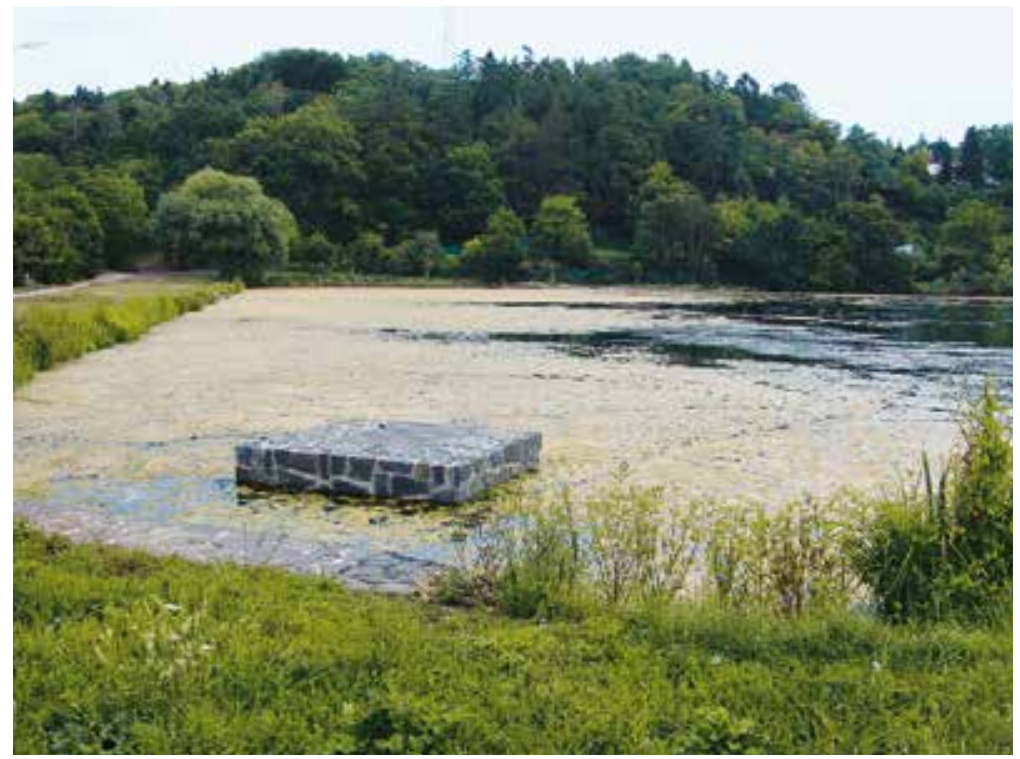

Obr. 23. Libocký rybník s porosty makrofyt (Myriophyllum sp., Lemna sp.)

Fig. 23. Libocký pond with the macrophyte vegetation (Myriophyllum sp., Lemna sp.)

V letním období došlo v rybníce k masovému rozvoji zelené řasy Hydrodictyon reticulatum, která vytvářela rozsáhlé makroskopické sítě zaplňující objem rybníka. Po odumření biomasy této zelené řasy zarostl rybník vegetací makrofyt (Myriophyllum sp., Lemna sp.), viz obr. 23. Za uvedených podmínek nemohl rozvoj fytoplanktonu v rybníce ve větší míře nastat. Vzhledem k značně vysokému obsahu celkového fosforu (průměrná hodnota 0,5 mg..$^{-1}$ ) a chlorofylu-a v profilu Džbán-př́tok (až 84,7 $\mu \mathrm{g}$. $1^{-1}$ ) dochází v nádrži, která je využívána ke koupání a rekreaci, k silnému rozvoji fytoplanktonu a v letním období k výskytu vodního květu sinic.

\section{Fytoplankton}

Analýza druhového složení fytoplanktonu profilů Motolského a Litovického potoka byla zaměřena především na období s výskytem vysoké biomasy řas. Struktura společenstva fytoplanktonu byla velmi pestrá, charakteristická prítomností velkého množství taxonů, zejména zelených řas (Chlorophyceae). Ze skupiny kokálních zelených řas se vyskytovaly druhy rodů Aktinastrum, Coelastrum, Crucigenia, Crucigeniella, Desmodesmus, Dictyosphaerium, Monoraphidium, Oocystis, Pediastrum, Planktosphaeria, Scenedesmus, Tetraedron, Terastrum. Zelení bičíkovci byli zastoupeni druhy rodů Chlamydomonas, Pandorina, Phacotus, Pteromonas. Vodní květ, tvořený kokální sinicí Microcystis aeruginosa, byl v průběhu sledování zaznamenán na rybníce Břve a nádrži Džbán. Uvedené kvalitativní složení fytoplanktonu je charakteristické pro ekosystémy rybníků.

\section{Zooplankton}

Druhové složení zooplanktonu vybraných rybníků a nádrží v povodí Motolského a Litovického potoka bylo orientačně sledováno v červenci a řijnu. Analyzovány byly vzorky odebrané z rybníků Mlýnský, Pivovarský, R1, R3 a nádrže Homolka na Motolském potoce a z rybníků Bašta, Strahovský, Břve, Litovický, Libocký a nádrží Jiviny a Džbán na Litovickém potoce.

Složení zooplanktonu ve sledovaných lokalitách indikuje vysokou rybí obsádku - společenstvo je tvořeno výhradně drobnými zástupci, kteří odolávají predačnímu tlaku ryb.
Sledované nádrže Ize podle převažujícího složení zooplanktonu rozdělit do několika skupin:

- s dominancí vírníků (Rotifera): většinou rod Keratella (především K. quadrata, K. cochlearis), Brachionus (B. calyciflorus, B. urceolaris), Asplanchna priodonta; $\checkmark$ některých navíc Polyarthra dolichoptera, Filinia longiseta, Synchaeta sp.: Mlýnský rybník, rybník Bašta, nádrž Homolka;

- s dominancí klanonožců (Copepoda): především drobní zástupci: Microcyclops bicolor, Cyclops strenuus, Paracyclops sp., Thermocyclops sp., méně - zvláště v jarním období - Eudiaptomus gracilis; ve všech lokalitách se trvale vyskytují kopepoditová a naupliová stadia: rybníky Pivovarský, Břve, Strahovský a nádrž Jiviny;

- s dominancí drobných perlooček (Cladocera): predevším Bosmina longirostris, Daphnia galeata, Ceriodaphnia sp.: rybníky R1, R3 a Litovický, nádrž Džbán.

Výjimkou ve složení společenstva zooplanktonu byl Libocký rybník. Ačkoliv jde o obhospodařovaný rybářský revír, v jarním a časně letním období rybník vykazoval stadium „čisté vody“, pro které je charakteristický výskyt velkých perlooček. V prípadě Libockého rybníka byla dominantním druhem perloočka Daphnia magna. Po rozkladu enormní biomasy zástupců mikro- i makroflory, která se vyskytovala $\vee$ rybníce $v$ letním období (obr. 23), byli v řínnovém zooplanktonu zjištěni už jen drobní zástupci (především Rotifera, Eudiaptomus gracilis, kopepoditová a naupliová stadia, Bosmina longirostris, Ceriodaphnia sp.).

\section{ZÁVĚR}

Výsledky sledování kvality vody Motolského a Litovického potoka, které probíhalo v teplotně výrazně nadprůměrném a srážkově chudém roce 2018, dokumentují horší stav $v$ Litovickém potoce jak z hlediska obsahu sledovaných živin, tak př́tomnosti vysoké biomasy fytoplanktonu. Hlavní důvody tohoto stavu Ize spatřit v odlišném charakteru povodí obou potoků. Na rozdíl od relativně malého povodí Motolského potoka je povodí Litovického potoka rozsáhlejší, zahrnuje zemědělsky využívanou krajinu, potok protéká oblastí s větším počtem lidských sídel rozptýlených v povodí. Lze tak předpokládat př́sun znečištěných povrchových vod i komunálního znečištění drobnějšími toky $\checkmark$ povodí (potoky Jenečský, Zličínský, Řepský). Do Litovického potoka ústí také odtok z čistírny odpadních vod pod městem Hostivice. Na kvalitu vody v potoce má vliv intenzivní rybářské využití rybníků na horním úseku toku. Také př́tomnost, v řadě prípadů, extrémní biomasy fytoplanktonu zpětně ovlivňuje kvalitu vody, zejména kyslíkové poměry, a přispívá k organickému zatížení.

\section{Poděkování}

Př́spěvek vznikl za podpory projektu CZ.071.02/0.0/0.0/16_040/0000382 Rekreační potenciál vody $v$ Praze - stav a výhledy rešeného v rámci operačního programu Praha - Pól rưstu II. 


\section{Literatura}

[1] Dostupné z: www.praha-priroda.cz/vodni-plochy-a-potoky

[2] Hostivice 1998: Sborník o prírodě, památkách a historii města. ČSOP Hostivice, 1998, 92 s

[3] ČSN EN ISO 5667-6 (75 7051). Kvalita vod - Odběr vzorků - Část 6: Návod pro odběr vzorků z řek a potoků. Praha: ÚNMZ, 2017.

[4] ČSN EN ISO 5667-4 (75 7051). Kvalita vod - Odběr vzorků - Část 4: Návod pro odběr vzorků z jeze a vodních nádrží. Praha: ÚNMZ, 2018

[5] ČSN EN ISO 7150-1 (75 7451). Jakost vod - Stanovení amonných iontů - Část 1: Manuáln spektrofotometrická metoda. Praha: ČNI, 2007.

[6] ČSN EN ISO 10304-1 (75 7391). Jakost vod - Stanovení rozpuštěných aniontů metodou kapalinové chromatografie iontů - Část 1: Stanovení bromidů, chloridů, fluoridů, dusičnanů, dusitanů fosforečnanů a síranů. Praha: ÚNMZ, 2009.

[7] ČSN EN ISO 6878 (75 7465). Jakost vod - Stanovení fosforu - Spektrofotometrická metoda s molybdenanem amonným. Praha: ČNl, 2005

[8] ČSN EN ISO 10260 (75 7575). Jakost vod - měření biochemických ukazatelů - Spektrofotometrické stanovení koncentrace chlorofylu-a. Praha: ČNI, 1996.

\section{Autoři}

RNDr. Blanka Desortová, CSc.

凶blanka.desortova@vuv.cz

RNDr. Ladislav Havel, CSc.

凶ladislav.havel@vuv.cz

Mgr. Jan Št'astný, Ph.D.

凶jan.stastny@vuv.cz

Výzkumný ústav vodohospodářský T. G. Masaryka, v. v. i.

Příspěvek prošel lektorským řízením.
WATER QUALITY OF THE PRAGUE'S STREAMS. PART 1: MOTOLSKÝ AND LITOVICKÝ STREAMS

\section{DESORTOVA, B.; HAVEL, L.; STASTNY, J.}

TGM Water Research Institute, p.r.i.

Keywords: Prague streams - water quality -

nutrients - phytoplankton - zooplankton

Results of water quality observation in the selected profiles on the Motolský and Litovický streams during the year 2018 are presented. Monitoring of water quality parameters was focused mainly on the nutrients content (nitrogen and phosphorus), chlorophyll-a concentrations and on the phytoplankton and zooplankton species composition. Data obtained show a worse state of water quality in the Litovický stream from both nutrient concentrations and phytoplankton biomass overgrowth, when compared to the Motolský stream. Water quality of the Litovický stream is mainly influenced by a nutrients input from agricultural land, municipal sewage and by water discharge from sewage treatment plants in its catchment. 